\title{
POLICY CHANGES AND ITS ENFORCEMENT TOWARD FOREIGN WORKERS IN HOTEL INDUSTRY
}

\author{
Rozila Ahmad ${ }^{1}$, Rohana Abdul-Rahman ${ }^{2}$, Che Su Mustaffa ${ }^{3}$, Nurhazani Mohd Shariff ${ }^{4}$, Noor
} Azimin Zainol ${ }^{5}$, Jasmine Zea Raziah Radha Rashid Radha ${ }^{6}$

1 School of Tourism, Hospitality and Event Management, Universiti Utara Malaysia, Sintok, Kedah.

Email: rozila@uum.edu.my

2 School of Law, Universiti Utara Malaysia, Sintok, Kedah.

Email: hana@uum.edu.my

3 School of Multimedia Technology and Communication, College of Arts and Sciences, Universiti Utara Malaysia, Sintok, Kedah.

Email: chesu402@uum.edu.my

4 School of Tourism, Hospitality and Event Management, Universiti Utara Malaysia, Sintok, Kedah.

Email: hazani@uum.edu.my

5 School of Tourism, Hospitality and Event Management, Universiti Utara Malaysia, Sintok, Kedah.

Email: azimin@uum.edu.my

6 School of Tourism, Hospitality and Event Management, Universiti Utara Malaysia, Sintok, Kedah.

Email: jasmine@uum.edu.my

\section{Article Info:}

\section{Article history:}

Received date:20.03.2019

Revised date: 02.05.2019

Accepted date: 02.01.2020

Published date: 13.03.2020

\section{To cite this document:}

Ahmad, R., Abdul-Rahman, R., Mustaffa, C. S., Shariff, N. M., Zainol, A., \& Radha, J. Z. R. R. (2020). Policy Changes and Its Enforcement toward Foreign Workers in Hotel Industry. Journal of Tourism, Hospitality and Environment Management, 5 (18), 01-09.

DOI: $10.35631 / J T H E M .518001$.

\begin{abstract}
:
The change of government after the 14th Malaysian general election is followed by some changes in government policies and practices. Hence, business practices including those in the service industry are also affected. Among the issues raised in the Dewan Rakyat is regarding the employment of foreign labour. While the news has broadcasted information regarding efforts to reduce the number of foreign workers in Malaysia under the new government, scholarly article regarding the matter remains scarce. This paper tracks the current policies on foreign workers and their enforcement effort. Findings from secondary data reveal that there are some changes in policies that regulate foreign workers' employment, and there is stricter enforcement of the regulations. While the local employees can rest assured that there will be fewer competition for jobs, it is also crucial for them to improve their attitude and increase their productivity.
\end{abstract}

Keywords:

Policy, Foreign workers, Hotel, Malaysia 


\section{Introduction}

The change of government after the $14^{\text {th }}$ Malaysian general election is followed with some changes in government policies and practices. Organizations do not operate in vacuum. Organizations must be proactive and make necessary changes suitable with its environmental changes, especially when the changes are related to law and regulations. Hence, business practices including of those in the service industry must comply with the new regulation. Among the issues raised in the Dewan Rakyat is regarding the employment of foreign labour (FreeMalaysiaToday, 2018). For decades, the Malaysian economy has relied heavily on foreign labours (Ismail, Yussof \& Awad, 2014; Nah, 2012). An influx of foreign labours will not only decrease the economic benefit to Malaysia, but it will also reduce the employment of native workers and dampens wage growth (Ismail \& Yuliyusman, 2014). The situation can be worsened by the influx of illegal immigrants workers who do not pay foreign workers' levy. Furthermore, the illegal immigrants are also involved in illegal activities (Abdul-Rahman et al., 2012; The Star Online, 2018). While the news has broadcasted information regarding efforts to reduce the number of foreign workers in Malaysia (FreeMalaysiaToday, 2018), scholarly article regarding the matter remains scarce. The objective of this study is to track the changes in foreign workers' policy and its enforcement and investigate how it affects the employment of foreign workers in the hotel industry. The research question of this study is "What are the changes in foreign worker's policy and enforcement efforts?" and "What is the current status of foreign workers' employment in luxury hotels".

\section{Literature Review}

In this study, foreign labour refers to those from other countries who have been recruited legally or illegally to work in Malaysia. Foreign labours are also known as temporary workers (Taylor \& Finley, 2010). Foreign labours can be categorized as skilled, semi-skilled and unskilled (Ismail et al., 2014). Usually, workers who travel to other countries to obtain work are unskilled (Taylor \& Finley, 2010). In Malaysia, foreign labours are allowed to work for up to five years, after which they must pass a skills test in order to stay on as a skilled worker (Nah, 2012). The government clearly states that the period allowed for the employment of a foreign labour is " 5 years +5 years" (Ministry of Home Affairs, 2018). At present, a foreign worker's employment period could be extended to 13 years with an annual levy of RM10,000 after the 10th year (Free Malaysia Today, 2018).

In service sector, foreign workers are employable in laundry and cleaning industries, charity houses, golf clubs, hotels and resorts (Datu-Eranza \& Awang-Razli, 2013). Based on Ministry of Home Affairs portal (2018), for hotel industry, the ministry allows the employment of foreign labours from Thailand, Philippines, Cambodia, Myanmar, Laos, Vietnam, Kazakhstan, Nepal, Pakistan, Sri Lanka, Turkmenistan, Uzbekistan, Bangladesh and Indonesia. The demand for foreign labours in the hotel industry is highly elastic compared to other service sectors such as wholesale and retail trade (Ismail, Yussof \& Uddin, 2012). The elasticity of demand for products and services in the hotel industry explains the elasticity of demand for foreign labours. The elasticity of demand for foreign labours makes it easier to replace foreign labour with other means of increasing productivity and performance in the industry, especially when the employment of the foreign labours is outsourced. Based on Jong (2016), foreign labours are employed on contract basis. Some hotels outsource the employment of foreign labours through agents. In this situation, the foreign labours are the employees of the agents. It is the agent who handles the errands related to their visa and the foreign labours receive their pay from the hoteliers through the agent. Companies or hotels that are using agencies must ensure that the agents are registered with the government (MOHA, 2018). It is difficult to monitor agents who 
are not registered, and there is a risk of them to breach the law such as being involved in human trafficking and labour exploitation (New Straits Times, 2018).

On the surface, hiring foreign workers appears to be costly and difficult to the employers. To hire foreign workers, employers must gain approval in advance. The hotel's recruitment process involves an interview by a panel from the Ministry of Tourism and Culture (MOTAC) on the employer or authorized representative. The panel represents the ministry who is the regulatory agency (Ministry of Home Affairs, 2018). Foreign workers passes are employer-sponsored, and they are issued for a specific job (Nah, 2012). The employers are required to pay for foreign labour levy and the fees for processing working permit and visa (Teh, Sum \& Lee, 2015). Employers must pay RM2,129 to cover for an employee's yearly levy, visa and the processing fee. In addition, it is mandatory for employers to ensure all foreign workers employed and pay the annual premium for the foreign workers (Ministry of Home Affairs, 2018). However, the burden of levy is passed to the foreign labours as the employers are required to pay minimum wages to the migrant workers (Hector, 2013).

Hector (2013) describes the foreign labours in Malaysia as cheap, vulnerable and easily exploitable. Besides having to pay for the foreign worker's levy, the foreign labours are not allowed to change employer, and employers are allowed to instruct their foreign workers to work for more than eight hours per day or more than forty-eight hours a week. Hector's description of foreign labour in Malaysia is supported by a number of studies (Devadason \& Chan, 2014; Kaur, 2008; Lee, 2017). However, after the new government takes over, a few of the rules on foreign workers have been changed. Such rules are based on government policy aimed at reducing dependence on foreign labour (The Straits Times, 2018). In effect these rules regulate the employers and foreign labours by imposing strict code of conduct for them to follow.

\section{Method}

This study uses primary and secondary data. Using secondary data from 20 press release, this study tracks the policy and regulatory changes under the new government. News cuttings related to foreign labours were retrieved online. The news was released by The Star, Bernama, The Straits Times, The New Straits Times, Free Malaysia Today News and Human Resources Online. All the news cuttings were dated from June 2018 to January 2019. Only consistent news across various press was used, and only the press with the most comprehensive data is cited in this study.

To answer the second research question, primary data was collected by interviewing five-star hotel managers in Kedah and Penang. The two states were selected because they have the highest number of five-star hotels in the Northern Region. Malaysia's Northern Region is comprised of four states, namely Perak, Penang, Kedah and Perlis. All the states have five-star hotels except Perlis. Perak has only two five-star hotels. Thus, Perak and Perlis were excluded from the primary data collection. The qualitative approach is conducted to search the key idea behind the research problems and to learn real issue from participants. Qualitative approach is a form of interpretive inquiry that helps the researcher to develop a complex overview of the problems and issues under study, and also will generate primary data for analysis to explain the phenomenon holistically (Creswell, 2014). In qualitative research, researchers collect data in the real industry field where participants experience the issue or problem under study.

Qualitative method is costly and time-consuming (Sekaran, 2003). Therefore, data can be gathered only from a few respondents. Data is collected through interviews with managers from 
Human Resource Department using an interview protocol. Qualitative data was collected from June until December 2018. The total number of five-star hotels in Kedah and Penang based on the data given by the Tourism Licensing Division as updated on the 18th October 2016 is 17. Nine hotels were located in Kedah and eight were in Penang. All the five-star hotels were contacted to request for an interview but only five agreed to participate while others claimed that they do not have the time for the interview. Four of the managers were from hotels in Kedah, and one from Penang. Table 1 lists the number of five-star hotels in the Northern Region and the managers interviewed.

Table 1: Five-Star Hotels in The Northern Region and The Respondents

\begin{tabular}{cccc}
\hline State & $\begin{array}{c}\text { Number of } \\
\text { Hotels }\end{array}$ & $\begin{array}{c}\text { Managers } \\
\text { Interviewed }\end{array}$ & Region \\
\hline Kedah & 9 & 4 & Northern \\
Penang & 8 & 1 & \\
Perak & 2 & 0 & \\
Perlis & 0 & 0 & \\
\hline
\end{tabular}

All primary and secondary data was analysed using thematic content analysis, a suitable technique to analyse data from press releases and interviews (Bowen, 2009). Content analysis is a "research technique for making replicable and valid inferences from data to their context" (Krippendorff, 1980, p. 21). The analysis focused on the grouping of data into meaningful categories of themes. Content analysis can be used in qualitative and quantitative method. Thematic content analysis is also known as qualitative content analysis. Qualitative content analysis involves the locating of materials, developing the materials and grouping them into categories, evaluating the significance, applicability and strength of the categories and reporting the outcomes (Jennings, 2010). The inductive structure of qualitative content analysis entails the process of condensing raw data into themes or categories. The themes or categories that are based on valid inference and interpretation emerged as data, and the data is constantly examined and compared (Zhang \& Wildemuth, 2009).

\section{Findings and Discussion}

Secondary data was used to answer the question "What are the changes in foreign worker's policy and enforcement efforts?" Finding from secondary data that was obtained from press release discovered three themes regarding foreign worker's policy and one theme regarding its enforcement. The themes are developed based on the search for the answer to the research question and the identification of common data that extend across the press released. Following are the four major themes:

\section{The End of 3+1 Amnesty Programme}

Amnesty programme, which pardon is granted to illegal immigrants started in 2014 . The $3+1$ amnesty programme enables illegal immigrants to pay a RM300 fine and then pay a RM100 fee for a special pass allowing them to return home. The immigrants bear the transportation cost to return home, and if they cannot afford it, then their respective embassies or family members must cover the cost (The Star Online, 5 Aug. 2018). The government allowed for an extension of three years for foreign workers who had 10 years of experience. However, under the new government, the Amnesty programme has been discontinued. The 3+1 amnesty programme ended on $30^{\text {th }}$ August 2018 (The Straits Times, 30 Aug. 2018). 


\section{Foreign Worker Levy Is Fully Borne by Employer}

On $25^{\text {th }}$ March 2016, the Cabinet decided that the levy, amounting up to RM10,000 per worker each year, would be paid by employers starting Jan 1, 2018 (The Star Online, 14 Sept. 2018). The annual levy of RM10,000 is applicable only for foreign workers who have worked in Malaysia for more than 10 years and are allowed to extend their permit for a maximum of three years. The RM10,000 payment is fully borne by the employer. However, the levy for new foreign labour remains at RM1,850 (Human Resources Online, 26 Sept. 2018).

\section{Only Local Cooks Allowed for Local Food Outlets Serving Malaysian Food}

Starting Jan 1 2019, restaurants serving Malaysian food could only hire locals as Cooks. The requirement was only applicable to "ordinary local food" outlets and not to foreign cuisine restaurants which require specialized chefs (Free Malaysia Today News, 26 July 2018).

\section{Stricter Enforcement}

Ops Mega 3.0, which started on July 1, 2018 is an enforcement effort by Malaysian Immigration against the illegals by conducting operations to arrest illegal immigrants and detain their employers (The Star Online, 5 Aug. 2018). Following the expiry of the $3+1$ amnesty programme (from August 31,2018) the operation against illegal foreign workers is heightened to a nationwide large-scale (The Star Online, 27 Aug. 2018). Between January 1 and December 6, 2018, a total of 45,499 illegal immigrants were arrested by the Immigration Department. Within the same period, 1,323 errant employers were detained for hiring or protecting illegal immigrants, and the majority of them had been charged in court (New Straits Times, 9 Dec. 2018).

Primary data provides information on the current status of foreign workers' employment in luxury hotels. Out of 17 hotel managers contacted, only five agreed to be interviewed. However, the information obtained is sufficient to answer the research question because all the participants were knowledgeable and informative. They are given codenames to ensure their anonymity. HRDK1 is the Human Resource Director in K1 hotel (the first participant in Kedah), HRDK2 is the Human Resource Director in K2 hotel (the second participant in Kedah), HRDK3 is the Human Resource Director in K3 hotel (the third participant in Kedah), TEK4 is the Training Executive in K4 hotel (the fourth participant in Kedah), and TEP1 is the Training Executive in P1 hotel (the first participant in Penang). Table 2 lists the participants profile such as their designation, experience and code name. Included is the information about the hotel's code, location and the percentage of their foreign labours.

Table 2: Respondents Profile and The Percentage of Their Foreign Labours

\begin{tabular}{llllll}
\hline Designation & Experience & $\begin{array}{l}\text { Hotel } \\
\text { Code }\end{array}$ & $\begin{array}{l}\text { Hotel } \\
\text { Location }\end{array}$ & $\begin{array}{l}\text { \% of Foreign } \\
\text { Labour }\end{array}$ & $\begin{array}{l}\text { Respondents } \\
\text { Code Name }\end{array}$ \\
\hline HR Director & 8 years & K1 & Kedah & 0 & HRDK1 \\
HR Director & 30 years & K2 & Kedah & 22 & HRDK2 \\
$\begin{array}{l}\text { HR Director } \\
\text { 11 years }\end{array}$ & K3 & Kedah & 0.5 & HRDK3 \\
$\begin{array}{l}\text { Executive } \\
\text { Training }\end{array}$ & 23 years & K4 & Kedah & 10 & TEK4 \\
Executive & 6 years & P1 & Penang & 0 & TEP1 \\
\hline
\end{tabular}


Finding from primary data discovered three themes:

\section{Some Hotels Employ Foreign Labour but The Number is Decreasing}

Three five-star hotels interviewed hire foreign workers whom are manage by agents. K2 has the highest percentage of foreign labour compared to other five-star hotels. Foreign workers are given the opportunity to grow from semi-skilled to skilled worker at this property. However, when they have reached their time limit, they must return to their home country. HRDK2 stated with a sad tone "Mr. X was brought in as semi-skilled 10 years ago. Then, he grows. He has to go back. 10 years already. Cannot continue." Following K2 is K4. TEK4 stated "Unskilled foreign labour, we have 10 percent."

As in Kedah, some hotels in Penang employ foreign labour. However, the number of foreign labours employed is decreasing.

Some hotels in Penang do employ foreign workers but only for the back of the house such as Housekeeping. The immigration doesn't encourage the employment of foreign labours. So it is getting lower and lower. They (other hotels) say it is difficult to find locals, but we can. (TEP1)

\section{Foreign Labours Are Employed Through Agents}

All 3 hotels employ their foreign labours through agents. TEK4 stated "They are categorized as contract workers whom we outsourced." Similarly, K2 and K3 also employ foreign labours through agents. They employ the foreign labours through agents because it is easier as it requires less administrative work. However, it is more expensive.

We employ through agencies... Technically it is easier and more expensive. Twelve solid hours they work. If there are those that do not perform, we just ask the agent to replace them. Less administrative work to us. They can remain productive for 12 hours. The Nepalese, Arun, comes to work at 8 am and return home at 7. Not even a day of MC. Really dependable. (HRDK2)

We do have a couple of foreign labours, but they are from third party. We do not have those directly on us. We only have 0.5 and they are in food and beverage division. F\&B service. They are from Philippines. Everyone else are local. (HRDK3)

\section{Hotels Can Survive Without Foreign Labour but It Is Challenging}

According to HRDK1, the decision to employ foreign labour depends on the hotel. HRDK3 stated "We need foreign labours because of shortage of manpower, but we can manage without them, that is why we only have 0.5 ." $\mathrm{K} 1$ hotel owner tries not to employ foreign labour although it is difficult to survive without them.

It depends on the hotels. Like K2 and Hotel X (non-respondent), they have many foreign labours. Many hotels are looking for foreign labours. Actually, it is difficult for hotels in Langkawi to survive without foreign labours. Because, firstly, people do not want to work here. The Langkawi people went out from Langkawi to find work. They go to Kuala Lumpur or Johor, where the salary is higher. (HRDK1) 
P1, a hotel located in Penang does not employ foreign labour because they can attract and retain the employment of local employees who are from the neighbouring states such as Kedah and Perak. TEP1 stated "Rank and file employees, many are from Penang and Kedah. They travel every day from Sungai Petani, Kulim, a few from Perak. We get employees from northern sides".

In summary, findings from primary and secondary data indicates that hotels need to employ foreign labour due to manpower shortage. However, the need of foreign labour in the hotel industry is minimal. In other words, hotels can survive without foreign labour, but it is challenging. The stricter enforcement by the new government requires hotels to face the challenge instead of finding an easy way out.

\section{Discussion}

Findings from the press release reveals that the new government has ended the $3+1$ amnesty programme which is followed by a strict enforcement by the Immigration Department. In addition, the new government requires that foreign worker's levy is fully borne by the employer, and foreign cooks are not allowed for local food outlets serving Malaysian food.

Past studies have criticized Malaysia's migration goals, policies and practices to be lacking in humanitarian concerns towards foreign labours (Devadason \& Chan, 2014; Hector, 2013; Kaur, 2008; Lee, 2017). While it is unjust to compare Malaysia's humanitarian effort with rich and developed countries, Malaysia's government has increased its humanitarian effort despite its financial situation. Making the employers to fully bear the foreign labours levy and enforcing Minimum Wage Legislation that does not discriminate foreign workers are seen as the Malaysia's government initiatives to abide to International Labour Standard and increase humanitarian concerns towards foreign labours. International Labour Standard which serves as a framework for national law and policy on migrant workers prohibited discrimination on account of nationality, race, religion or sex (International Labour Organization, 2016). Past studies have mentioned about poor law enforcement (Devadason \& Chan, 2014). Comparison between Ops Mega 2 and Ops Mega 3 provide evidence of a stricter law enforcement. While the former is short and temporary, the latter does not have a deadline and shall continue until the situation has improved. The law enforcement against illegal immigrants and their employers should be supported and not criticized as it also helps mitigate human trafficking and exploitation.

Malaysia's humanitarian initiatives by making the employers to fully bear the foreign labours levy and enforcing Minimum Wage Legislation that does not discriminate foreign workers may risk losing Multi-National Companies investment in Malaysia due to heightened labour cost (Teh, 2015). The native workers in Malaysian hotel industry has been criticized to be less productive compared to the foreign workers (Ahmad, Scott \& Abdul-Rahman, 2016; DatuEranza, \& Awang-Razli, 2013). Therefore, it is crucial for the Malaysian workforce in the hotel industry to increase their productivity, consistent with their wage increase. On the other hand, it is important for the employers in the hotel industry to provide a good working environment in order to attract and retain employees.

The importance of attractive compensation, training and opportunities for career development to attract and retain employees in the hotel industry have been highlighted in a number of studies (Ferrary, 2015; Mohammed et al., 2013; Warech \& Tracey, 2004; Willie et al., 2017). Thus, it is suggested that compensation and human capital investment may overcome labour 
shortage issues and reduce dependence on foreign labour in the hotel industry. However, based on the findings of this study, it is proposed that the dependence on foreign labour is also affected by the governing regulations on foreign workers and their enforcement. In other words, it is proposed that the new regulations and stricter enforcement will reduce the number of foreign workers employed in the hotel industry.

This study contributes to theory and industry, especially hotel industry by providing the current information about policies on the foreign workers and its enforcement. Hotel managers need to be alert of policy changes as it affects their operation. Failure to comply with the law will result in lawsuits that would be very costly to the organization in terms of financial and public image. This study also provides information on the current situation of foreign labour employment in luxury hotels, including the percentage of foreign labours employed. However, the findings of this study have three limitations. Firstly, Bowen (2009) cautioned that documents such as newspaper releases "should not be treated as necessarily precise, accurate or complete recordings of events that have occurred" (p. 33). Although the findings presented in this study are consistent data across various sources, information such as RM10,000 levy per foreign worker each year is not included in the Ministry of Home Affairs' website. Therefore, it is crucial for researchers to be continuously updated by the latest news. Secondly, the findings of this study cannot show causal effect. Although this study discovered that the number of foreign workers employed is decreasing, the proposition that it is caused by the new regulations and stricter enforcement requires support from a quantitative study. Finally, the findings of this study cannot be generalised. Although this study discovered that foreign labours are employed through agents, a quantitative study with an appropriate sampling is needed for generalization as this study only interview five out of 17 hotels. Other hotels that refuse to participate might directly employ the foreign labours as their full-time employees.

\section{Acknowledgement}

This study is funded by the Ministry of Higher Education under Fundamental Research Grant Scheme.

\section{References}

Abdul-Rahman, H., Wang, C., Wood, L. C., \& Low, S. F. (2012). Negative impact induced by foreign workers: Evidence in Malaysian construction sector. Habitat International, 36(4), 433-443.

Ahmad, R., Scott, N. \& Abdul-Rahman, R. (2016). Why minimum wage order implementation is a challenge to human resource manager in Langkawi hotels. International Journal of Culture, Tourism and Hospitality Research, 10(2), 1750-6182.

Bowen, G. (2009). Document analysis as a qualitative research method. Qualitative Research Journal, 9(2), 27-40.

Creswell, J. W. (2014). Research Design: Qualitative, Quantitative \& Mixed Methods Approaches (4th ed., pp. 1-273). London: Sage Publications.

Datu-Eranza, D. \& Awang-Razli, I. (2013). Foreign employment and employability in hotels at Kuala Lumpur and Sabah. Proceedings of the 6th International Conference of the Asian Academy of Applied Business, Bandung, 2013.

Devadason, E. \& Chan, W.M. (2014). Policies and laws regulating migrant workers in Malaysia: A critical appraisal. Journal of Contemporary Asia, 44(1), 1-15.

Ferrary, M. (2015). Investing in transferable strategic human capital through alliances in the luxury hotel industry, Journal of Knowledge Management, 19(5), 1007-1028.

Free Malaysia Today News. (2018). Retrieved from https://www.freemalaysiatoday.com 
Hector, C. (2013). Cheap, vulnerable and easily exploitable migrant workers in Malaysia. FOCUS Asia-Pacific, 71, 2-6.

Human Resources Online. (2018). Retrieved from https://www.humanresourcesonline.net/

International Labour Organisation (ILO-ROAP). (2016). Review of Labour Migration Policy in Malaysia Tripartite Action to Enhance the Contribution of Labour Migration to Growth and Development in ASEAN (TRIANGLE II Project). Bangkok: ILO, 2016.

Ismail, R. \& Yuliyusman, F. (2014). Foreign labor on Malaysian growth. Journal of Economic Integration, 29(4), 657-675.

Ismail, R., Yussof, I. \& Awad, A. (2014). The impact of foreign labors on wages: A case study of Malaysian firms. International Journal of Economic Perspectives, 8(3), 64-75.

Ismail, R., Yussof, I. \& Uddin, N. (2012). Analysis of labor requirements in the Malaysian services sector. International Journal of Business and Management Science, 5(1), 1937.

Jennings, G. (2010), Tourism Research (2nd ed.), John Wiley \& Sons, Australia.

Jong, Y.H. (2016). The practice of organisational flexibility in Malaysian higher rated hotels. (Unpublished Dissertation, Universiti Utara Malaysia, 2016).

Kaur, A. (2008). International Migration and Governance in Malaysia: Policy and Performance. UNEAC Asia Papers, 22, 4-18.

Krippendorff, K. (1980). Content analysis: An introduction to its methodology. Beverly Hills, CA: SAGE.

Lee, H. (2017). Labour policies and institutions in the eleventh Malaysia plan: Aiming high, falling short. Journal of Southeast Asian Economies, 34(3), 552-70.

Ministry of Home Affairs. (2018). http://www.moha.gov.my/index.php/ms/bahagian-pa-dasardasar-semasa/dasar-semasa-penggajian-pekerja-asing

Nah, A.M. (2012). Globalisation, Sovereignty and Immigration Control: The Hierarchy of Rights for Migrant Workers in Malaysia. Asian Journal of Social Science, 40, 486-508.

Sekaran, U. (2003). Research Methods for Business: A Skill Building Approach (Fourth., pp. 1-450). Illinois: John Wiley \& Sons, Inc.

Taylor, M. \& Finley, D. (2010). Acculturation, assimilation, and retention of international workers in resorts. International Journal of Contemporary Hospitality Management, 22(5), 681-692.

Teh, C.G., Sum, K.M., \& Lee, M.S. (2015). An initial review of the implementation of the Malaysian Minimum Wage Order: A case for a win-win intention, implementation and enforcement. The Journal of Developing Areas, 49(4), 313-324.

New Straits Times. (2018). Retrieved from https://www.nst.com.my/

The Star Online. (2018). Retrieved from https://www.thestar.com.my/

The Straits Times. (2018). Retrieved from https://www.straitstimes.com/

Zhang, Y. \& Wildemuth, B.M. (2009). Qualitative analysis of content. In Wildemuth, B. (Eds.), Applications of Social Research Methods to Questions in Information and Library Science. Westport, CT: Libraries Unlimited. 